\title{
REPRODUCTION OF POLITICAL TERMS IN POLITICAL SPEECHES
}

\section{Hlavatska Yu. L.}

\section{INTRODUCTION}

The political sphere plays an important role in the life of society, so it is not surprising that it is the focus of attention of representatives of various branches such as political science, psychology, philosophy, sociology, economics, communication theory and linguistics as well. In particular, linguists-translators are interested in studying political texts as under modern conditions the latter are of special importance in the market of translation services, being a means of regulating relations in political sphere.

A political text is the subject of different scientific approaches, but most linguists believe that it should be studied taking into account the target attitudes of communicators, their views, beliefs and personal qualities, conditions of creation, functioning and perception of the text by the addressee, the connection of the very text with other ones. In other terms, nowadays a political text is vied in the dynamics of the communicative situation, as a discourse.

Currently, political discourse is seen as communication not only in the socio-political sphere (as the most effective way to solve a social problem), but also in the public sphere of communication (influencing the audience with important information), thus, emphasizing relations between social groups. Political discourse is "a set of all linguistic acts in political discussions, rules of public policy, sanctified by tradition and tested by experience"1; this set reflects the specific features of the mental world of politics.

Political speech is characterized by the expressions which comment on government action rather than the private conduct of an individual ${ }^{2}$.

Translation analysis of special vocabulary of various fields of knowledge, including political, in the focus of our attention. Special vocabulary includes categories, concepts, realia of various fields of knowledge, research methods and techniques, processes, properties, parameters. Terms make up most of the special vocabulary. They express

\footnotetext{
${ }^{1}$ Баранов А.Н., Казакевич Е.Г. Парламентские дебаты: традиции и новации. Москва : Знание, 2001. 145 с.

Legal dictionary. URL: http://www.duhaime.org/LegalDictionary/P/ PoliticalSpeech.aspx (дата звернення: 01.11.2020).
} 
various special names that form terminological systems. "And each terminological system means a system of concepts of certain sciences, scientific areas, and the realia of different fields of knowledge" ${ }^{\text {"3 }}$.

The translation of socio-political terms is gaining great importance now due to the expansion of foreign policy and economic ties between the states, the growing number of media, the number of contacts with foreign partners. The study of criteria and patterns of translation of terms of political discourse is relevant for translation studies, because socio-political terms constitute the very layer of the vocabulary covering the names and concepts of socio-political life of society; moreover, the terms closely correlate with other spheres of life.

Currently, the issue of studying discourse in general and its various types in particular is very relevant. Before focusing our attention on political discourse, we need to discuss the essence of discourse itself.

\section{Discourse, political discourse and political language}

According to a critical and analytical review of scientific papers focused on the definition of "discourse", there are many that contradict each other in this or other way. To illustrate the situation in detail we can refer to the definition of this concept from the standpoint of terminology. Discourse definitions given in the papers of such researchers as O. Akhmanova, V. Danilenko, O. Gerd etc. allow us to conclude that any term has generic and specific features, where the generic feature is responsible for assigning the term to the class of lexical units of natural language, and specific - for determining the specifics of the term in the concept or subject of special field.

The definitions given within communicative approach are of the greatest interest: "Discourse is a written or verbal product of communicative action"; "Discourse is a complex communicative phenomenon that includes the text as well as extralinguistic factors which affect its production and perception"; "Discourse is a communicative situation that includes the consciousness of communicators and the text" created in the process of communication; "Discourse is a text immersed in a situation of communication"; "Discourse is a coherent text in combination with extralinguistic, pragmatic and other factors, taken in the event aspect"; "Discourse is a communicative event

${ }^{3}$ Вакуленко М.О. Термін і термінологія: сучасні уявлення та концепції. Слово и словарь. Vocabulum et vocabularium: сборник науч. трудов по лексикографии / под ред. В.В. Дубичинского и Т. Ройтера. Харків : Підручник НТУ, 2011. Вып. 12. C. $140-145$. 
carried out in a certain cognitive and typologically conditioned communicative space" ${ }^{\text {. }}$.

Political discourse is a phenomenon that society faces every day. However, it can be assumed that there is no precise definition of "political discourse". Scholars analyze its broad and narrow varieties. Among the representatives of scientific schools O. Sheigal considers a broad definition of political discourse: "any language formations, the content of which belongs to the sphere of politics" categories of addressee relations in political communication, emphasizing the relevance of semiotic oppositions "people - power", "own - alien" (in other terminology: "friend - enemy"). O. Sheigal shows "how this semiotic opposition is represented by ideologues, invectives, pejoratives, ethnonyms, anthroponyms, political terms and other linguistic units" [ibid.].

The origins of modern political discourse can be found in ancient rhetoric. Politicians of ancient Rome and Greece were also interested in the subject of political eloquence. However, due to historical reasons, namely due to feudal rule, interest in the problems of eloquence was lost forever. And only with the construction of new democratic states and societies the possibility of the revival of political communication, the emergence of political discourse appeared.

"Political discourse is understood as a set of discursive practices that identify participants and form a specific topic of political communication. In other words, political discourse is constituted, on the one hand, by a set of topics that become the subject of discussion, and on the other - by accepted linguistic methods of discussion of these topics (discursive practices)" ${ }^{\prime \prime}$.

Dutch linguist, T. van Dijk, supports the consideration of a narrow form of defining political discourse. He believes that "political discourse is a class of genres that are limited to a particular social sphere, the sphere of politics"7. Special language and speech models distinguish political discourse from other ones, such as media, medical, advertising, etc.

${ }^{4}$ Кириченко T.C. Трактування терміна «дискурс» у сучасній лінгвістиці. URL: https://naub.oa.edu.ua/2014/traktuvannya-terminu-dyskurs-u-suchasnij-linhvistytsi/ дата звернення: 29.11.2020).

${ }^{5}$ Шейгал Е.И. Семиотика политического дискурса : дисс. ... докт. филол. наук : 10.02.04. Волгоград, 2000. 440 с.

${ }^{6}$ Баранов А.Н., Михайлова О.В., Сатаров Г.А., Шипова Е.А. Политический дискурс: методы анализа тематической структуры и метафорики. Москва : Фонд ИНДЕМ, 2004. 94 с. URL: http://www.indem.ru/PUBLICATII/TrudiFI/politichesky_ discurs.pdf (дата звернення: 23.10.2020).

${ }^{7}$ Ван Дейк Т.А. Дискурс и власть. Репрезентация доминирования в языке и коммуникации. URL: https://www.twirpx.com/file/1245827/ (дата звернення: 20.10.2020). 
Linguistic and speech models are formed in accordance with the functional orientation of political discourse, namely the mass addressee. Linguistic means must convey the opinion of a politician so that it is understood not only by his main recipient, but also perceived by all listeners.

Political discourse is limited by the professional framework of politicians; it is one of the varieties of institutional discourse. Properly selected forms of presentation of the material, the number of texts, persistence in defending their views in most cases lead to the achievement of a political goal. Political discourse is seen as institutional due to the fact that discussions of politicians take place in such an institutional environment as government meetings, parliamentary sessions, congresses of political parties.

The main task of political institutions is the struggle for power, its strengthening and maintaining. For this purpose rules, norms, rituals are developed. One of the rituals is a political speech. Texts are created by politicians and for them, transcripts of parliamentarians' speeches, political agreements are prepared and questions for interviews with politicians are developed. Journalists create mass media texts which are disseminated through the media.

Sources of political communication can be written or oral. Written sources include leaflets, program documents of political parties and movements. Politicians' speeches, which are recorded in the columns of newspapers and magazines, the president's address to the parliament, all sorts of slogans, are also among the written sources. Oral sources include conversations of political leaders during their meetings with voters, speeches made at rallies and during official ceremonies, parliamentary debates and political speeches. There is usually a distinction between direct dialogue and media broadcast. The main recipient of political information refers to the unfolding political events as a theatrical show, which is played out exclusively for him. By and large, the activity of spectators of a political performance is equal to zero and consists in passive observation of what is happening around them ${ }^{8}$.

In addition, some linguists include various comments, texts, and remarks in political discourse. A set of remarks, comments, and individual texts inherent in political communication can be found in blogs, on electronic sites, including letters and appeals to politicians and government agencies; moreover, anecdotes on political topics, poems with sharp political content can also be included into the list. Examples of political discourse embrace

8 Акінчиць Н.Г. Політичний дискурс як об'єкт наукового аналізу. URL: http://dspace.nbuv.gov.ua/bitstream/handle/123456789/54472/19-kinchits.pdf?sequence=1 (дата звернення: 30.10.2020). 
detective stories on political topics, memoirs written by politicians, as well as various texts on the topic of politics ${ }^{9}$.

O. Epstein distinguishes the most general semantic and pragmatic categories, the so-called peculiar signs within the composition of political discourse: the author's image, addressness, informativeness, intentionality, evaluation, convention, emotiveness/expressiveness, modality, intertextuality, socio-cultural context, the form of communication and its means ${ }^{10}$. However, it's necessary to point out individual signs peculiar only to this certain type of discourse. So, for example, specific descriptions of political discourse are agonality, aggressiveness, ideology and theatricality.

Thus, although political discourse is a phenomenon that society faces on a daily basis, it can be assumed that there is no clear definition of this concept. Special language and speech models distinguish political discourse from other ones. Political discourse is limited by the professional framework of politicians and belongs to the types of institutional discourse. Political communication can also be attributed to the institutional form of communication because it is characterized by social rules and specific boundaries of functioning, which it is impossible, in our opinion, to analyze without resorting to scientific approaches studying political discourse.

As is well known, changes in political life are reflected both in modern political discourse and in political language, which is a form of expression of a political text. According to A. Chudinov, the social demand for political linguistics is determined by the growing interest of society in the mechanisms of political language ${ }^{11}$. Therefore, the current problems of modern linguistics are the problems of studying political language and political discourse.

Political language refers to the basic concepts of political linguistics related to political communication. The system-forming function of political language is performed by socio-political vocabulary as a special lexical and phraseological subsystem of modern literary language. Socio-political vocabulary in conjunction with socio-political terminology makes up the socio-political vocabulary. It develops through historical realities and closely correlates with the general scientific vocabulary of the era.

By the socio-political vocabulary we imply "all the terminology of international relations and the world economy, the realia of domestic and

9 Лейчик В.М. Терминоведение: предмет, методы, структура. Москва : Изд-во ЛКИ, 2007. $256 \mathrm{c}$.

10 Эпштейн О.В. Семантико-прагматические и коммуникативно-функциональные категории политического дискурса. Филологические науки. Bопросы теории и практики. Тамбов : Грамота, 2008. № 2. С. 150-156.

${ }^{11}$ Чудинов А.П. Политическая лингвистика : учебное пособие. Москва : Флинта, Наука. 2006. 254 с. 
economic life of this country, all the symbols associated with the political system and socio-political life of other countries"12.

The concept of "socio-political term" is part of the terminology of the social sciences, which has the properties of ideology. Ideologization in this case should be understood as a reflection in lexical and semantic units of ideological views of native speakers. The terms acquire ideological colouring as a result of such methods of ideologization as metaphorization, metonymization, homonymization, synonymization, euphemization and the change of the emotional and evaluative components of meaning.

The following illustrations of the public speech of the former President of the USA, Donald Trump, at a press briefing at the White House emphasize the above thesis, namely the use of the word "unleashing" in combination with "America's medical genius" and "a rapid recovery" constitute a political metaphor. The politician uses these statements to smooth over the most important problem not only for the United States but for the whole world - the problem of the coronavirus: "By cutting red tape and unleashing America's medical genius, we've reduced the fatality rate by $85 \%$ since April"; "Our plan is unleashing a rapid recovery, our opponent's plan would hurt America very badly, send us into a depression"13. The meaning of the lexical unit "unleashing" includes the seme of "releasing, being free". It should be noted that more often in electronic dictionaries we encounter the following phrases: "unleashing war, unleashing conflicts, and unleashing aggression". In this context the fight against the pandemic is compared to the fight for the presidential election, which has already taken place. A distinctive feature of this political term is its modal and expressive function.

There are various structural and semantic classifications of socio-political vocabulary, which are based on such important criteria as composition and thematic principle. In scientific circles one can trace different, sometimes polar, points of view on the definition of the term "socio-political vocabulary". Some researchers believe that the socio-political vocabulary is a wide range of lexical units, including all the vocabulary of socio-political texts. Others consider political vocabulary comprises both commonly used lexical items and terms. For example, V. Leichik refers purely scientific terms (terms of social and political sciences), professionalism and general literary words and expressions, nomenclature units, proper names, emotionally colored lexical

12 Токарева И.В. Аспекты терминологизации немецких лексических заимствований (сущность дефиниции терминопонятия «общественно-политическая лексика»). Актуальные вопросы филологических наук : материалы Междунар. науч. конф. Чита : Молодой ученый, 2011. С. 134-137.

13 Donald Trump White House Press Briefing Transcript September 23. URL: https://www.rev.com/blog/transcripts/donald-trump-white-house-press-briefing-transcriptseptember-23 (дата звернення: 11.10.2020). 
units to socio-political vocabulary ${ }^{14}$. However, in this case the boundaries of socio-political vocabulary are blurred; the composition is heterogeneous, so it becomes impossible to identify any common features that characterize this set of units in general, without which the allocation of a lexical and semantic subsystem is impossible.

Most of the socio-political vocabulary is formed by terms of other terminological systems: diplomatic and legal terms, terms of economics and international law, trade union vocabulary, names of government documents, etc. It also includes professional vocabulary as well as jargons. For example, the political jargon "Grand Old Party (GOP)" is used in the sense of the traditional nickname of the Republican Party and is widely used in political speeches of American politicians; political jargon "Commander in chief" is used as a constitutional role given to the president as head of the US military ${ }^{15}$ : "So I take very personally the profound responsibility of serving as Commander in Chief" 16 .

Analyzing the latest scientific papers focused on the study of the vocabulary semantic loading, three main criteria (correlation with sociopolitical terminology, thematic distribution and the degree of emotional colouring) should be taken into account while studying the structural and semantic classification of socio-political vocabulary. "As for the first sign, all general political vocabulary is divided into two large groups: general political vocabulary, which is the origin of terminology ("humanism", "democracy", "progress"), and vocabulary, which is not the origin of terminology"17.

The first group is divided into thematic groups according to the classification of social sciences: socio-political vocabulary, which is the origin of the terminology of jurisprudence, and so on. At the same time, on the one hand, ideological terminology occupies an unequal place in the dictionaries of various social disciplines; on the other hand, it passes to different degrees from the dictionaries of individual social sciences to the common language. From the point of view of emotional colouring, this part of the socio-political vocabulary is relatively neutral.

14 Лейчик В.М. Терминоведение: предмет, методы, структура. Москва : Изд-во ЛКИ, 2007. $256 \mathrm{c}$.

15 US election glossary: A-Z guide to political jargon. URL: https://www.bbc.com/news/election-us-2016-37385625 (дата звернення: 11.10.2020).

16 Donald Trump White House Press Briefing Transcript September 23. URL: https://www.rev.com/blog/transcripts/donald-trump-white-house-press-briefing-transcriptseptember-23 (дата звернення: 11.10.2020).

17 Холявко І.В. Суспільно-політична лексика у пресі 90-х років XX ст. (семантико-функціональний аналіз) : дис. ... канд. філол. наук : 10.02.01. Кіровоград, 2004. 229 c. 
Within the second group, political idioms of the language of mass communication ("iron lady", "dirty campaign", and "liberty") are singled out as a more emotionally coloured layer. In terms of thematic classification this vocabulary includes various realia and phenomena of both external and internal political life.

The remaining part of the socio-political vocabulary, by thematic feature, can be classified into two groups: 1 . The names of various public, party and state institutions and organizations, officials, social institutions, etc. ("Supreme Council"). 2. The second group consists of the names of various phenomena of public life and social realia characteristic of a particular social system ("Red and Blue States", "Great Depression").

As for the formation and functioning of socio-political vocabulary, these processes are closely correlated with the development of social concepts that reflect the dialectic of social development. Radical changes in the sociopolitical life of the country cause significant changes in the lexical and semantic system of language, especially in the field of socio-political vocabulary, which is quite natural.

I. Kholyavko singles out the following ways of forming socio-political vocabulary:

1. "Formation of new words with the help of their own word-building system, based on international elements, or through their combination" ${ }^{\text {"18 }}$ (the vivid illustration is the political term "Checks and Balances" - "Separation of control among three several government organizations (judiciary, legislature and executive division") ${ }^{19}$;

2. "Formation of new words from proper names" 20 (for example, the term "McCarthyism" - "the practice of accusing someone of being a Communist and therefore avoiding or not trusting them" $)^{21}$;

3. Borrowings (for example, the lexical unit "mandate" was borrowed from Latin (the first stage of borrowing), and later, according to the processes of assimilation of French words, this unit entered the English dictionary and is now actively used in speeches of political leaders: "We'll

18 Холявко І.В. Суспільно-політична лексика у пресі 90-х років XX ст. (семантико-функціональний аналіз) : дис. ... канд. філол. наук : 10.02.01. Кіровоград, 2004. 229 c.

19 Cambridge Dictionary. URL: https://dictionary.cambridge.org/ru/checks-andbalances (дата звернення: 30.11.2020).

20 Холявко І.В. Суспільно-політична лексика у пресі 90-х років XX ст. (семантико-функціональний аналіз) : дис. ... канд. філол. наук : 10.02.01. Кіровоград, 2004. 229 c.

${ }^{21}$ Cambridge Dictionary. URL: https://dictionary.cambridge.org/dictionary/english/ mccarthyism (дата звернення: 30.11.2020). 
have a national mandate to wear a mask-not as a burden, but to protect each other" $)^{22}$.

G. Solovei distinguishes three main groups of political terms: 1) political terms ("resignation", "enforcement activity"); 2) political realia ("Secretary of the Department of Premier and Cabinet", "the Department of Health and Human Services", "National Cabinet"); 3) political symbols ("Nation's Founders", "The Cold War") ${ }^{23}$.

Thus, we can conclude that the concepts of "socio-political vocabulary" and "socio-political terms" are in most cases synonymous in modern linguistics, but both should be considered in the context of socio-political translation to identify general issues of their reproduction at the lexical level, namely elucidation of translation methods of English terms of political discourse.

\section{The ways of political terms reproduction}

Socio-political translation performs two functions: introductory and stimulating. The purpose of the introductory function is to specifically and objectively inform the reader about current issues. For example, in his speech at the Republican Congress, Donald Trump informed the audience about the production of the coronavirus vaccine, specifically naming the deadlines and readiness for further struggle: "In recent months, our nation and the entire planet has been struck by a new and powerful invisible enemy. Like those brave Americans before us, we are meeting this challenge. We are delivering lifesaving therapies and will produce a vaccine before the end of the year, or maybe even sooner. We will defeat the virus and the pandemic and emerge stronger than ever before" ${ }^{\text {" } 24}$.

The stimulating function is actualized in the fact that the socio-political text has a certain effect on the reader in order to form a certain attitude to the socio-political article, view of the described event, positive or negative assessment of reality. Donald Trump expresses his positive as well as negative assessment of events in one sentence: "And yet despite all of our greatness as a nation, everything we have achieved is now in danger. This is

22 Donald Trump White House Press Briefing Transcript September 23. URL: https://www.rev.com/blog/transcripts/donald-trump-white-house-press-briefing-transcriptseptember-23 (дата звернення: 11.10.2020).

23 Соловей Г.С. Політична лексика як об'єкт перекладу (на матеріалі текстів політичних заяв, звернень, промов, статей та анекдотів) : автореф. дис. ... канд. філол. наук : 10.02.16. Херсон, 2011. 20 с.

24 President Trump's Republican National Convention Speech. URL: https://www.nytimes.com/2020/08/28/us/politics/trump-rnc-speech-transcript.html (дата звернення: 13.10 .2020$)$. 
the most important election in the history of our country" 25 - the greatness of the nation is in danger, and the upcoming elections (the $3^{\text {rd }}$ of November, 2020) are the most important in the history of the country.

The translation of a socio-political text can perform a political function (establishing recommendations, rules of international conduct in the political arena, individual reflection of political events) ${ }^{26}$. Donald Trump, on the eve of the US presidential election, expresses his own vision of the actions of his opponent, Joe Biden, as follows: "Joe Biden is not a savior of America's soul. He is the destroyer of America's jobs, and if given the chance, he will be the destroyer of America's greatness. For 47 years, Joe Biden took the donations of blue-collar workers, gave them hugs, and even kisses, and told them he felt their pain, and then he flew back to Washington and voted to ship our jobs to China and many other distant lands"27.

P. Newmark clarifies that the main problems in translation arise at the lexical level (translation of words, phrases, set expressions, idioms, neologisms, non-equivalent vocabulary, etc.) and divides them into two types: 1) when the translator does not understand the lexical unit (the problem arises when the translator does not know all the meanings of the word, or the meaning is revealed by the context, or the word is used in an unusual word usage); 2) when it is difficult for a translator to transfer a lexical unit into the language of translation (different semantic range of lexical units in the source text and the target one $)^{28}$.

Using the lexico-semantic analysis of English political speeches of famous world leaders and their official translations into Ukrainian we have found words, phrases and sentences for which there are equivalent (dictionary) correspondences ("a nисlear war" - «ядерна війна», «aggressive separatism» - «агресивний сепаратизм», "cardinal rule" «кардинальне правило», "political class" - «політичний клас», "sovereignty" - «суверенітет» etc.); for which the translator tries to find the equivalent of many meanings given in the dictionary or those that the context suggests ("rhetorical fire" - «пристрасне бажання» ("rhetorical" - «риторичний, пихатий, пишномовний»; "fire" - «вогонь, полум'я, пожежа, займання, горіння, запал, натхнення, пристрасть,

25 President Trump's Republican National Convention Speech. URL: https://www.nytimes.com/2020/08/28/us/politics/trump-rnc-speech-transcript.html (дата звернення: 13.10 .2020$)$.

${ }^{26}$ Trosborg A. Text Typology: Register, Genre and Text Type. Text Typology and Translation. Amsterdam/Philadelphia : John Benjamin's Publishing Company, 1997. P. 3-23.

27 President Trump's Republican National Convention Speech. URL: https://www.nytimes.com/2020/08/28/us/politics/trump-rnc-speech-transcript.html (дата звернення: 13.10 .2020$)$.

${ }^{28}$ Newmark P. A Textbook of Translation. L. : Prentice Hall, 1988. 293 p. 
несамовитість»); for which the translator creates his "own" equivalent, or translates a word that is not given in the dictionaries; it requires applying certain interlingual transformations ("a COVID-normal" - «mі випадки запалення легенів, які не кваліфікуються як короновірус»).

Translation problems practically do not arise when reproducing common words and expressions, as well as words that have unambiguous correspondences in the target text, among which the following groups of lexical units of the socio-political sphere should be distinguished in English and Ukrainian:

1) socio-political and political terms ("peer" - "nep", "anti-migrant" «антимігрант», "British home Secretary" - «Британський Міністр внутрішніх справ», "immigration minister" - «міністр імміграціï», "the Brexit referendum" - «брексит (або бретзит)-референдум»);

2) proper names (in the vast majority the names of politicians and public figures, geographical names that are important in the political sphere) ("Alf Dubs" - «Альф Дабс», "Harold Macmillan" - «Гарольд Макміллан», "Hugh Gaitskell" - «Хью Гейтскелл», "Tony Blair" - «Тоні Блер»);

3) names of organizations and parties ("Federalist Party" «Федералістська партія», "Ноияе of Соттопs" - «Палата Громад», “Anti-Administration Party" - «Партія проти адміністрації»);

4) some everyday words and phrases related to the social and political life of society ("Nazi оссираtion" - «нацистська окупаиія», "climate change" - «зміни клімату», "hитапе, tolerant country" - «гуманна, толерантна краӥна»).

Lexical units used in political speeches to attract attention, increase the informativeness of the text, a certain communicative effect on the recipient, of course, are part of the socio-political text and problematic for the translator:

1) Special terms in the field of politics and public life ("collapse" «крах, розвал, обвал», “ехрапsion" - «розвиток, розиирення, експансія», "fascism, tyranny, and communism" - «фатизм, тиранія та комунізм», “referendum" - "референдум", «аппехатіоn" - «приєднання, анексія») ${ }^{29}$. When reproducing such lexical items, it is recommended to use generally accepted lexical items that are understandable to a wide audience.

2) Neologisms that reflect socio-political processes and ideological concepts ("Grexit" (Greece + exit) - «Грекзит» (acceptable exit of Greece from the European Union), "Brexit" (Britain + exit) - «Брексит» (expected exit of Great Britain from EU), "Brexiteers" - «mi, хто підтримує ідею брекситу», "extremist" (ekstrem + -ist) - «екстреміст», "republocrat"

${ }^{29}$ Vocabulary: Political Words. URL: https://www.scholastic.com/teachers/articles/ teaching-content/vocabulary-political-words/ (дата звернення: 11.10.2020). 
(rерисlican + democrat $)$ - «політик однієї з двох найбільших політичних партій, про якого кажуть, щзо він поводиться так, неначе належить іншій napmіiі»; among them political labels, which are attached to certain political figures or eponyms ("Obamacare" - «реформа охорони здоров'я Барака Обами», “trumpianity” - «політична позиція Дональда Трампа»).

In political speech of Joe Biden we find: "America is not just a collection of clashing interests of Red States or Blue States" $"$. A search on google.com shows that the term describes the states of the United States, whose residents mostly vote for Republicans ("red states") and Democrats ("blue states"). The Multitran dictionary provides the following translation of the phrase "red states": «червоні» штати - ие штати, які голосують за республіканиів. The phrase "blue states" is reproduced in the dictionary as «сині» штати голосують за демократів ${ }^{31}$. The translator may use previously created tracing «червоні» and «сині» итати, as this option is often used in the media.

3) Colloquial vocabulary (slang) is a special lexical and phraseological layer, which includes words and expressions that used to be the property of limited use, but later became commonplace and were subjected to semantic and expressive-stylistic processing; the conceptual uncertainty of slang is somehow erased. For example: "the First Black President" («nершuй чорний президент») - Bill Clinton was called in such a way for his supporting African Americans; Abraham Lincoln was called "Honest Abe" for his principled honesty. As is clear from the above examples, the translator must provide a translation comment.

4) Complex words formed by "holophrase-type transposition" ("compression words" or "multicomponent lexical items"): "once-in-acentury pandemic" - «пандемія, яка траплясться раз у сторіччя», "We're-going-to-do-this" - «Ми зробимо ие» ${ }^{32}$. Descriptive translation is a detailed explanation of a foreign word or phrase. The need for such a method of translation arises if there is no realia in the target language.

5) Abbreviations to denote the names of organizations, professions, positions ("ICU" - «інвестииійна банківська кампанія»; "VICPOL" «полічія штату Вікторія» (Australia); "DHHS" - «Відділ Оздоровчих $i$ Людських Послуг» (Australia); “FDA" - «Управління по санітарному

30 Joe Biden's full 2020 Democratic National Convention speech. URL: https://www.cnbc.com/2020/08/21/joe-biden-dnc-speech-transcript.html (дата звернення: 10.10.2020).

31 Multitran dictionary. URL: https://www.multitran.com/m.exe?11=1\&12=2 (дата звернення: 17.10.2020).

32 NY Gov. Andrew Cuomo Conference Call Transcript October 14. URL: https://www.rev.com/blog/transcripts/ny-gov-andrew-cuomo-conference-call-transcriptoctober-14 (дата звернення: 15.10.2020). 
нагляду за якістю харчових продуктів і медикаментів»; "CARESAct (Coronavirus Aid, Relief, and Economic Security Act)" - «законопроєкт, підписаний президентом Дональдом Трампом у березні 2020 року у відповідь на економічні наслідки від пандемії COVID-19 у Сполучених Wmamax». Due to intercultural differences with English, there are no corresponding equivalents in Ukrainian, as a result, translators choose a descriptive method for more adequate and clear deciphering of abbreviations.

6) Figurative comparisons, metaphor, metonymy, elements of irony: "People feel like we are on this carousel where another black life is being taken" ${ }^{33}$ - «Людям здається, що вони знаходяться на цій каруселі, де забирають ще одне чорне життя». This illustration, which we took from Donald Trump's political speech, contains the lexical unit "carousel". According to the results of work with the dictionary of symbols (thesaurus method of analysis), the carousel as an image is part of such concepts as "wheel", "circle", "rotation". Used in a symbolic sense, this concept, according to interpreters of symbolism, means the following: the wheel symbolizes the splitting of the world into two essentially different factors rotational motion and immobility and illustrates the escape from the illusory world, the world of rotation; the circle serves as a symbol of eternity, perfection and heaven ${ }^{34}$. The phrase «political carousel" is used in politics: «жаргонна назва виду порушення на виборах, що проводяться шляхом таємного голосування». In this context, we can say that the "carousel" symbolizes, firstly, the traditional tactics and strategies of the election campaign of any country, when there are certain battles between opponents of political programs, and, secondly, a certain immobility regarding the state of Afro-Americans and the problem of coronavirus in the United States. Thus, the translator preserves this image in the target text ("preservation of the image in the target language" according to the classification of P. Newmark ${ }^{35}$ ).

7). Quotations, other people's statements: "Really brilliant Kentucky attorney general, Daniel Cameron, is doing a fantastic job. I think he's a star. And he made a statement that I'll just read. "Justice is not often easy. It does not fit the mold of public opinion. And it does not conform to shifting standards. It answers only to the facts and to the law. If we simply act on emotion or outrage, there is no justice. Mob justice is not justice. Justice sought by violence

33 Donald Trump White House Press Briefing Transcript September 23. URL: https://www.rev.com/blog/transcripts/donald-trump-white-house-press-briefing-transcriptseptember-23 (дата звернення: 11.10.2020).

${ }^{34}$ Керлот Х.Э. Словарь символов. Москва : REFL-book, 1994. 608 c.

${ }^{35}$ Newmark P. A Textbook of Translation. L. : Prentice Hall, 1988. 293 p. 
is not justice. It just becomes revenge" ${ }^{36}$ - «Дійсно блискучий генеральний прокурор Кентуккі, Деніел Кемерон, робить фантастичну роботу. Я думаю, що він зірка. I він зробив заяву, яку я зараз прочитаю. «Справедливість часто буває нелегкою. Це не укладається в громадську думку. I це не відповідає стандартам, щзо міняються. Вона відповідає тільки фактам і закону. Якщо ми просто діємо під виливом емочій або обурення, справедливості немає. Правосуддя натовпу - це не справедливість. Справедливість, до якої прагнуть насильством - ие не справедливість. Це просто стає помстою». Here the translator finds direct equivalents to the reproduction of such terms as "justice", "violence", "revenge", "standards", "law", "public opinion".

We can conclude that when reproducing English terms in the texts of political discourse the following translation techniques as transliteration, tracing, transcription, search for direct equivalents, descriptive translation are used.

\section{CONCLUSIONS}

Thus, the involvement of general scientific and descriptive analytical research methods have allowed us to establish that nowadays discourse is interpreted differently: a complex communicative phenomenon, a communicative situation, a coherent text with extralinguistic, pragmatic and other factors to be combined as well as a communicative event.

Through the use of descriptive analytical method of analysis, we've found that a political text is a broad term that covers a wide variety of texts and genres performing different functions according to political attitudes, the thematic content of which is mainly related to politics: political activity, political ideas, political connections, parliamentary debates, speeches and statements of politicians, political documents, articles, essays, etc.

Socio-political vocabulary is heterogeneous in its composition and content (it includes terminological and non-terminological lexical units pointing out social and political phenomena of society). Socio-political terminology includes terms used to denote the organization of the state, the nature of the relationship between its members, the way of governing society.

These differences do not exclude the systemic connection of sociopolitical vocabulary with socio-political terms. The accessibility of the media to a wide audience and the political competence of the population expand the scope of socio-political terms usage, which is perceived and

${ }^{36}$ Donald Trump White House Press Briefing Transcript September 23. URL: https://www.rev.com/blog/transcripts/donald-trump-white-house-press-briefing-transcriptseptember-23 (дата звернення: 11.10.2020). 
understood by the majority of society. Some terms of the science of society may go beyond the scope of narrow usage as a result of events occurring in society, and become important and relevant for their description.

Involvement of translation analysis has let us conclude that when reproducing English terms in the texts of political discourse the following translation techniques as transliteration, tracing, transcription, search for direct equivalents, descriptive translation are used.

The study of grammatical features of the reproduction of socio-political terms, attributive phrases, for instance, may be in the focus of our perspective studies.

\section{SUMMARY}

The article is focused on highlighting the main items of discourse studying in general and political discourse in particular. The question of their linguistic and stylistic perspective with an emphasis on the peculiarities of English socio-political terms reproduction is considered to be topical. Internal problems of linguistic theory, the need to study political thinking and political behaviour, the desire of progressive members of society to free themselves from those who manipulate the public consciousness of shameful politicians - these are the factors that determined the process of political discourse in historical retrospect. Political discourse is limited by the professional framework of politicians and belongs to the types of institutional discourse. The general semantic and pragmatic categories of political discourse include: the image of the author, addressability, informativeness, intentionality, evaluation, conventionality, emotiveness/ expressiveness, modality, intertextuality, socio-cultural context, form of communication and its ways of actualization. The following characteristics are typical of modern English political discourse: borrowings, book words, clichés, set phrases, common and author's abbreviations, references and quotations, proper names, adjectives formed from surnames, neologisms, various expressive means and professional political terminology. The core interest is directed to the studying of translation means of English terms reproduction in the texts of political speeches such as transliteration, tracing, transcription, search for direct equivalents, descriptive translation.

\section{REFERENCES}

1. Баранов А.Н., Казакевич Е.Г. Парламентские дебаты: традиции и новации. Москва : Знание, 2001. 145 с.

2. Legal dictionary. URL: http://www.duhaime.org/LegalDictionary/P/ PoliticalSpeech.aspx (дата звернення: 01.11.2020).

3. Вакуленко М.О. Термін і термінологія: сучасні уявлення та концепції. Слово и словарь. Vocabulum et vocabularium: сборник науч. 
трудов по лексикографии / под ред. В.В. Дубичинского и Т. Ройтера. Харків : Підручник НТУ, 2011. Вып. 12. С. 140-145.

4. Кириченко Т.С. Трактування терміну «дискурс» у сучасній лінгвістиці. URL: https://naub.oa.edu.ua/2014/traktuvannya-terminudyskurs-u-suchasnij-linhvistytsi/ (дата звернення: 29.11.2020).

5. Шейгал Е.И. Семиотика политического дискурса : дисс. ... докт. филол. наук : 10.02.04. Волгоград, 2000. 440 с.

6. Баранов А.Н., Михайлова О.В., Сатаров Г.А., Шипова Е.А. Политический дискурс: методы анализа тематической структуры и метафорики. Москва : Фонд ИНДЕМ, 2004. 94 с. URL: http://www.indem.ru/PUBLICATII/TrudiFI/politichesky_discurs.pdf (дата звернення: 23.10.2020).

7. Ван Дейк Т.А. Дискурс и власть. Репрезентация доминирования в языке и коммуникации. URL: https://www.twirpx.com/file/1245827/ (дата звернення: 20.10.2020).

8. Акінчиць Н.Г. Політичний дискурс як об'єкт наукового аналізу. URL: http://dspace.nbuv.gov.ua/bitstream/handle/123456789/54472/19kinchits.pdf?sequence=1 (дата звернення: 30.10.2020).

9. Лейчик В.М. Терминоведение: предмет, методы, структура. Москва : Изд-во ЛКИ, 2007. 256 с.

10. Эпштейн О.В. Семантико-прагматические и коммуникативнофункциональные категории политического дискурса. Филологические науки. Вопросы теории и практики. Тамбов : Грамота, 2008. № 2. C. $150-156$.

11. Чудинов А.П. Политическая лингвистика : учеб. пособие. Москва : Флинта, Наука. 2006. 254 с.

12. Токарева И.В. Аспекты терминологизации немецких лексических заимствований (сущность дефиниции терминопонятия «общественно-политическая лексика»). Актуальные вопросы филологических наук : материалы Междунар. науч. конф. Чита : Молодой ученый, 2011. С. 134-137.

13. Donald Trump White House Press Briefing Transcript September 23. URL: $\quad$ https://www.rev.com/blog/transcripts/donald-trump-white-housepress-briefing-transcript-september-23 (дата звернення: 11.10.2020).

14. US election glossary: A-Z guide to political jargon. URL: https://www.bbc.com/news/election-us-2016-37385625 (дата звернення: 11.10.2020).

15. Холявко І.В. Суспільно-політична лексика у пресі 90 -х років XX ст. (семантико-функціональний аналіз) : дис. ... канд. філол. наук : 10.02.01. Кіровоград, 2004. 229 с.

16. Cambridge Dictionary. URL: https://dictionary.cambridge.org/ru/ checks-and-balances (дата звернення: 30.11.2020). 
17. Cambridge Dictionary. URL: https://dictionary.cambridge.org/ dictionary/english/mccarthyism (дата звернення: 30.11.2020).

18. Соловей Г.С. Політична лексика як об'єкт перекладу (на матеріалі текстів політичних заяв, звернень, промов, статей та анекдотів) : автореф. дис. ... канд. філол. наук : 10.02.16. Херсон, $2011.20 \mathrm{c}$.

19. President Trump's Republican National Convention Speech. URL: https://www.nytimes.com/2020/08/28/us/politics/trump-rnc-speechtranscript.html (дата звернення: 13.10.2020).

20. Trosborg A. Text Typology: Register, Genre and Text Type. Text Typology and Translation. Amsterdam/Philadelphia : John Benjamin's Publishing Company, 1997. P. 3-23.

21. Newmark P. A Textbook of Translation. L. : Prentice Hall, 1988. 293 p.

22. Vocabulary: Political Words. URL: https://www.scholastic.com/ teachers/articles/teaching-content/vocabulary-political-words/ (дата звернення: 11.10.2020).

23. Joe Biden's full 2020 Democratic National Convention speech. URL: https://www.cnbc.com/2020/08/21/joe-biden-dnc-speech-transcript.html (дата звернення: 10.10.2020).

24. Multitran dictionary. URL: https://www.multitran.com/ m.exe?11=1\&12=2 (дата звернення: 17.10.2020).

25. NY Gov. Andrew Cuomo Conference Call Transcript October 14. URL: $\quad$ https://www.rev.com/blog/transcripts/ny-gov-andrew-cuomoconference-call-transcript-october-14 (дата звернення: 15.10.2020).

26. Керлот Х.Э. Словарь символов. Москва : REFL-book, 1994. 608 с.

\section{Information about the author:} Hlavatska Yu. L.,

Candidate of Philological Sciences, Associate Professor, Associate Professor at the Department of Tourism, Hotel, Restaurant Business and Foreign Languages Kherson State Agrarian and Economic University 23, Stritenska str., Kherson, 73006, Ukraine 